\title{
HOW BOOKS STOP TIME: THE PROBLEM OF ORIGINALITY AND ARTISTS' BOOKS
}

\author{
BYMICHAEL JOSEPH
}

\begin{abstract}
Michael Joseph is a rare book librarian at the Rutgers University Libraries and founding director of the annual New Jersey Book Arts Symposium at the John Cotton Dana Library in Rutgers-Newark
\end{abstract}

By representing bookishness in nontraditional forms, book artists have opened up new ways of thinking about and theorizing about The Book. Books represented as coffee tin wrappers, glass coronets in a pool of Parish blue, painted undergarments, as hats and boots and Dr. Seuss-like musical instruments in a wordless performance that itself pantomimes the temporality and interpretive choreography of reading, liberate the imagination from the dead letter of convention. This rigorous, forty year project of interrogating the premises of the codex book has, with increasing energy and, some might say, shamelessness, exposed The Book as a notional reality, a powerful symbolism subject to seemingly inexhaustible figuration.

"It is this experience of the sacred," writes Mircea Eliade, "that generates the idea of something which really exists and, in consequence, the notion that there are absolute intangible values which confer a meaning upon human existence" "Structure and Changes in the History of Religion,"366).

The task of this paper is to suggest how the artists'book constitutes the experience of Eliade's "sacred," within a discussion of the implications of originality and the concomitant problems of Aristotelian and non-Aristotelian time.

The term original and its grammatical forms are commonly used to denote historical or morphological priority. So we read that Sean Connery was the "original" 007. Or, in Christian countries, the power of swearing "originated" in the Mosaic injunction against taking the name of Jehovah in vain. Manhattan was "originally" covered by dense forest inhabited by the Lenape, which other Algonquin thought to be the "original" inhabitants of Earth, and called them, alternatively, "grandfather." These few examples help us to see that the everyday concept of "original" as "first" presupposes a prior acceptance of succession and sequence. We would not say the sun and moon are our original sun and moon, even though there are no anteceding suns or

Journal of the Rutgers University Libraries, Volume LX, pp. 95-II3

Copyright 2003 by the Rutgers University Libraries. All rights reserved. 
moons. For something to be original, something else must stand in a peculiar relationship to it, characterized by qualities of derivation or reference.

Obviously, this is a very literal, boring truth, and of no use to those who spend little real time on the literal level. In order for something to be "original," it really suffices that we postulate originality and recognize some determining relationship between our understanding of originality and some event that we construct as primary. Although we are barred from directly apprehending originality in the sun and the moon, simile and metaphor permit us this apprehension indirectly. In the poetry of courtly love, for example, the sun signifies the original color or luminosity of a beloved's fair hair and the moon the ethereal power of her penetrating gaze. At the conclusion of "The Song of Wandering Angus," Angus vows to search forever for the magical female being that has bewitched him into an awareness of the beauty of the world- "raised his consciousness" as we used to say. Angus imagines that he will find her,

And kiss her lips and take her hands;

And walk through long, dappled grass,

And pluck till time and times are done

The silver apples of the moon,

The golden apples of the sun.

(Collected Poems 1956, 58)

Here, the sun and moon are original in the sense that printing plates are, imprinting the apples that are themselves symbols of the exquisite revolutions of a kind of languorous pagan paradise where one succumbs endlessly to the sensual pleasures, the forbidden knowledge, of silver and golden apples. In this trope, the sun and moon become "original" symbols of eternal refreshment, unfaltering, idealized youth, and a property of the later, secondary thing - the creative force of the apples-supplies the context in which the sun and moon can be perceived as original.

The relationship between an art object and some anteceding original, in which the distinctive quality of the original is manifest in a purified or essential form, has become such a commonplace within the popular imagination that when, for example, a film reviewer writes, Renée Zellweger is this generation's Madeline Kahn, nobody wonders what he means. 
My hypothesis is that this kind of complex play, integral as it is to symbolic thought, contradicts fundamental assumptions about time, or, elicits a horizon in which time can be perceived as something other than unidirectional and unrecoverable.

The opposite, prevailing construction of time as an inherent order of events and as the broadest possible framework within which humans can consider things, including themselves, in their multifarious relationships, and ultimately, their significance begins with Aristotle.

Previously, philosophers regarded time as circular, endlessly repetitive. Nothing ever happened once, but every event occurred ad infinitem, according to immutable laws and definite alternations. Certain thinkers of antiquity believed that Homer would compose his epics over and over, that Socrates would again and again be charged, condemned, swallow poison and expire. The clearest articulation of the ancient view of time as "repetition and eternal return," or anukuklosis, occurs in Plato's Politicus. Time is "the circular motion of the heavens," Plato says. "Once the Universe attains the duration that befits the Universe, it reverses direction," and this event signals "the greatest destruction, both among animals in general and among the human race, of which ... only a few representatives remain" (Myth of the Eternal Return, I2I). This cosmic catastrophe precedes a paradoxical regeneration. People "begin to grow young again: 'the white hair of the aged darkens,' while those at the age of puberty begin to lessen in stature day by day, until they return to the size of a new-born infant; then finally, still continuing to waste away, they wholly cease to be" (ibid). The body of those who died at this time dematerialize, without leaving a trace, after a few days. Anukuklosis sheds light on the symbolic universe in which Renée Zellweger is this generation's Madeline Kahn, or, to look ahead, William Morris's Chaucer's Canterbury Tales can be "the finest book since Gutenberg" (Private Presses, 43).

However, as rationalists, we also occupy — and perhaps have to ourselvesa different universe, one dominated by the uniqueness and irreversibility of temporal events. "Time," wrote Aristotle, "is something counted in connection with motion that is encountered in the horizon of the earlier and later." Aristotle's motion relative to the "earlier and the later" is uniformly in one direction, from earlier to later. After Aristotle, no philosopher or theologian returned to the idea of events in time being reversible or repeatable, with the exception of Henri Bergson. 
In Time and Free Will, Bergson critiqued Aristotle's notion of an all encompassing time as "nothing but a ghost of space haunting the reflective consciousness" (Time, 98). By permitting a sense of space to "trespass" upon the earlier "pristine" time sense, human consciousness gradually came to "separate the present state from its former states" (Time, 99).

Bergson theorized that within the earlier perception, "the heterogeneous duration of the ego" perceived no "moments external to one another" (Time, I08). In other words, and in discussing artists' books "other words" are always necessary, at an earlier period in the evolution of human consciousness, what we moderns now experience as the unending ticking by of unique moments rather presented itself to sense and understanding as oscillations within an undifferentiated now.

The radical nature of Bergson's hypothesis provoked Martin Heidegger, who snapped-or seemed to snap-that one could not separate a sense of clock time from the reflective consciousness in the world. ${ }^{1}$ He hypothesized instead the priority of the calculating mind, and thus the impossibility of transcendence. No act, no event, no dream-nothing could exist outside of time: temporality suffused every pore of human experience, and thus whatever meaning life could offer was contingent, shaped and motorized by the vagaries of history.

In his studies in comparative religions, Mircea Eliade subsequently criticized Heidegger's historicist certainties, finding in them a certain amount of cultural constructiveness. "Historicism," he noted, "was created and professed above all by thinkers belonging to nations for which history has never been a continuous terror" (Myth, I52 n.). Eliade reinvested Bergson's concept of an archaic time sense within his dialectic of secular and religious or modern and traditional humanity, the central dialectical figure in his thought. It is Eliade who shows us how books are vehicles of transcendence: how they materialize a transhistorical meaning. How books stop time.

Traditional humanity "lives in two kinds of time," writes Eliade, "of which the most important [is] sacred time." Unlike the pre-Socratic Anukuklosis, sacred time is always potentially present. It does not recur on any plan, unlike the seasonal round with which Eliade's critics have often confused it, but is "periodically regenerated by means of rites" (Sacred and Profane, 70). In Eliade's writing, "rites" has a systematic, function-oriented and transparent significance, which is reflexive with the apprehension of sacred time. A rite constitutes a reactualization of the original gestures of exemplary models 


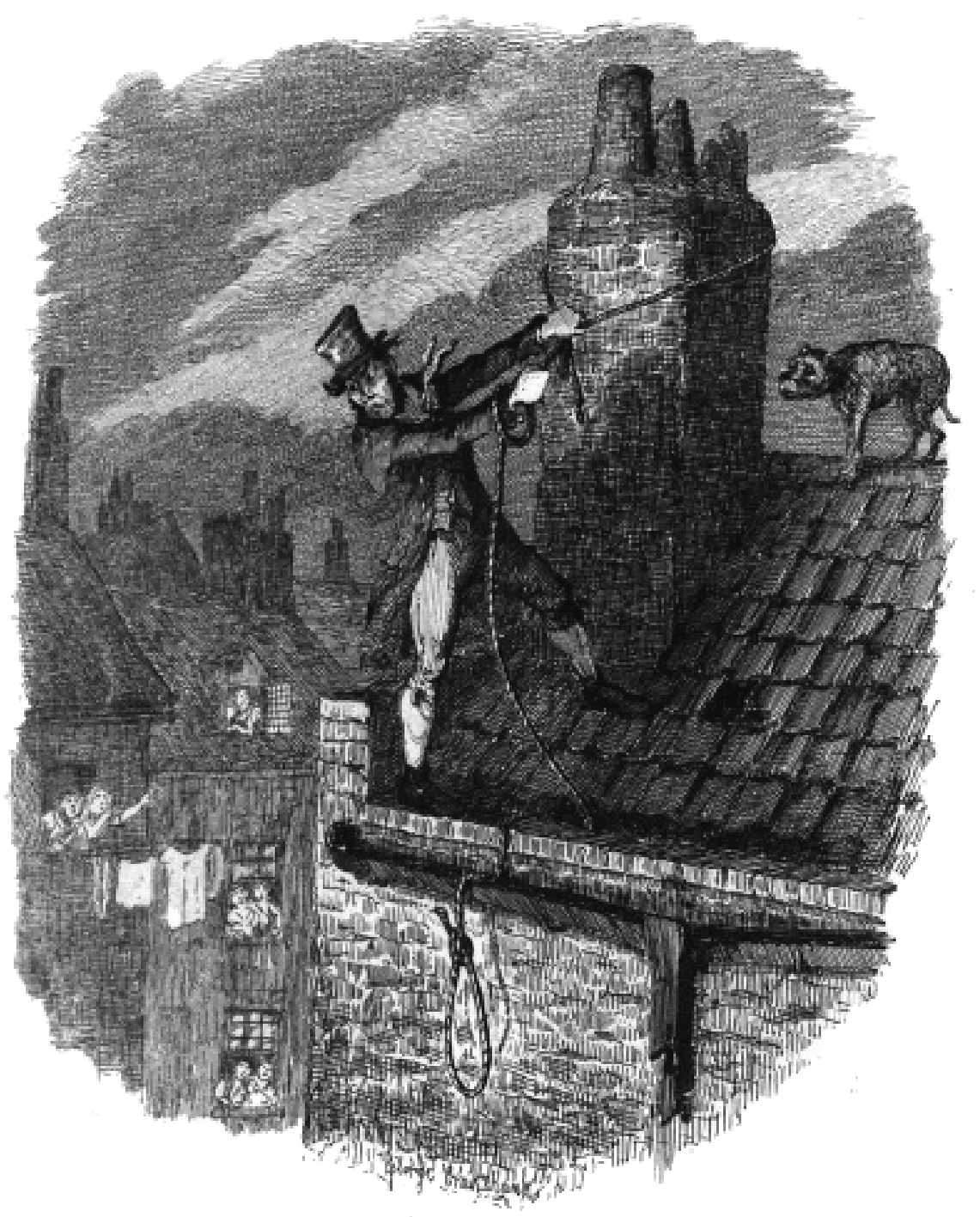

Figure 5.I George Cruikshank, Frontispiece to Oliver Twist (I838). The Book in a Parlous State. 
(i.e., gods, heroes, ancestors, anthropomorphic beings greater than ourselves and not bound by the same fragile conditions). Not only are the actions of the originating agency brought to life but so is the special time in which those actions occurred, which is sacred time, or is cognate with sacred time. To turn the metaphor completely around, a rite interrupts the linear experience, or illusion, of historical time.

The animating spirit of the rite is the notional power of repetition. Eliade dramatically emphasizes the dynamic relationship between repetition and archaic time.

Insofar as an act (or an object) acquires a certain reality through the repetition of certain paradigmatic gestures, and acquires it through that alone, there is an implicit abolition of profane time, of duration, of "History"; and he who reproduces the exemplary gesture thus finds himself transported into the mythical epoch in which its revelation took place. (Myth, 35)

Charles Wendell Beane sheds light on how any modern activity may be understood in terms of Eliade's understanding of the sacred of traditional humanity. In "Methodological, Pedagogical, and Philosophical Reflections on Mircea Eliade as Historian of Religions," he equates Eliade's notion to a "phenomenological description of a qualitative dimension of human experience" consonant with a European notion of the "religious." Oppositely, Eliade's profane can be "understood as phenomenologically descriptive of a quantitative dimension of human experience (life in the ordinary), which yet 'conceals' (Eliade) the potentially 'extraordinary." (Changing Religious Worlds, I68). The quantitative dimension actualizes the counting of time, whereas the qualitative dimension, "the extraordinary," annihilates it.

But to some extent Beane's explanation defers meaning. What exactly is "the extraordinary"?

Without conceding too much to relativism, let us admit that there is clearly a relativistic aspect to Beane's essentialized "extraordinary," appropriately since determinations of the extraordinary in a modern context are always mediated by empirical, subjective experience. Robert Graves, perhaps the greatest male love poet of the twentieth century, saw the extraordinary exploding from the ordinary in romantic love. 
There is one story and one story only
That will prove worth your telling,
Whether as learned bard or gifted child;
To it all lines or lesser gauds belong
That startle with their shining
Such common stories as they stray into.

(Collected Poems 1959,212)

The "one story" Robert Graves imagines in his poem "To Juan at the Winter Solstice" corresponds to what Eliade would call a "sacred history." While it is, in fact, a valorization of a private emotion, its meaning exists at the level of the universal. It is not a privileging of the first person. Living and telling the experience of love reactualizes the one, unimprovable original, whose power to transcend historical time also transcends the individuality of the persona, for whom its irresistible forcefulness is manifest by its "shining."

The traditional book arts, with their rigidly controlled application of obsolete technologies, and close-bound guilds, schools, chapels, typothetae, and annual wayzgoose festival, provide abundant unequivocal instances of valorized repetition and an irresistible, pervasive nostalgia for the fabulous era. This isn't to imply that the locus of one's desire is not ordinary, or that it is not quantitative. Merely that it is also extraordinary, as it manifests prestige or an aura, to use Walter Benjamin's term, within our specialized apprehensions. Even though our celebration involves concrete details and historical impact, or an explanatory power with regard to our own cultural moment, what we intend by that diverges from the random, miscellaneous flood of events, the quantitative dimension that constitutes the whole of material actuality, or a totalizing history. ${ }^{2}$ Our celebrations rather involve a perceived social and cultural coherence immanent in history, a qualitative construction that we can intelligibly relate to what we may select as the essence or the most interesting part of any specific event. ${ }^{3}$ Elaine Showalter's sensuous recollection, published in this journal, of gleaning "among old volumes of nineteenth-century journals and novels" idealizes fraying book bindings by invoking the prestige of Tess of the d'Urbervilles. Apprehending a homology between library stacks and the pastoral setting enables her to emerge from the stacks, a heroine of her own invention, not mussed by book rust, but "stained with the dyes and juices of books." 
Similarly, an artist who chooses to make a woodcut draws deliberately upon a tradition that traces back to the I470s, whereby the glamour of antiquity and a spirit of continuity and connectedness solemnize the work. The woodcut invokes the prestige of the origin qua the incunable period. Kerry Magruder suggests that historians J.D. Bernal and Daniel Boorstin make unconscious use of the woodcut in a related way, to symbolize a medieval belief in the flat earth. ${ }^{5}$ Presumably, the medium's flatness of representation and its concurrency with a geocentric worldview explain their unconscious motivation, naturalistically. But, taken as a category of thought, what seems affective about this symbolism is that it reinscribes a preCopernican, pre-modern cosmology, a worldview that once embraced the immutability of the heavens and the sacrality of space. Certainly, no woodcut artists subscribe to archaic beliefs about the flat earth or the perfection of the surrounding solar system, but they engage it on the level of the symbol. In terms of its interpretive power, or its pull against the vacuousness and evanescence of temporality, this palpability of an ascendant origin, conveyed through the sacred history of the origin of printing, assumes the ontological status and function of myth.

The historicity of Johan Gutenberg or a first fifty years of printing does not obviate the mythical status and function of this event and that person. Eliade lists numerous examples of the metamorphosis of historical events and historical persons into "a mythical category."

The barbarian invaders of the High Middle Ages were assimilated to the Biblical archetype Gog and Magog and thus received an ontological status ... a few centuries later, Christians were to regard Genghis Khan as a new David, destined to accomplish the prophecies of Ezekial (Myth, I42).

The incunable period-counted from the invention of printing from movable type in about I450 to I50I-is preeminent in the bibliographical mind as an age of unprecedented creative activity, elegized as the "cradle period of printing" and, with greater ceremony, "the nativity of printing." Connoisseurs and historians of printing alike have pronounced the 42 line Bible - the cradle book par excellence - to be the greatest book ever printed, the enduring standard for all subsequent typographic works. Few pronouncers will stop to ask by what criteria, aesthetic or otherwise, we can adjudicate 
among the wide world's teeming numbers of books. Like all myths, the criteria are self-evident (and if you are not so sure, your vote probably doesn't count). A perception of the nonpareil Gutenberg and the 42 line Bible is traditional, relativistic, and cherished by all self-selecting bibliophiles and hieratic rare book experts. Like all traditionalistic beliefs, it provides a "prereflective, positive valorization" of printing and typography, at least for those who share this particular Weltanschauung (Reconstructing Eliade, I44). ${ }^{6}$ Which is to say, for those who are disposed to perceive it, the 42 line Bible manifests charismatic, archetypal power, and it bestows ontological status upon all imitative typographic acts and, by extension, bookishness in general: the history, preservation, and representation of typography, the collection and exhibition of typographic artifacts. All of these interlinking, imitative practices become real because Gutenberg is real—not merely actual—and through them practitioners can participate in an exemplary pattern.

We see nostalgic longing for the time of the origin in the nominal recycling of the tools of traditional bookmaking. Type fonts, for example, invoke the auratic powers of marmorealized predecessors. Though aware of the physical differences between the types of Baskerville, Bodoni, Garamond, Plantin, Arrighi, Caslon, and our modern imitations, a palpable sense of a deeply mysterious and reciprocal bond between our typography and the original achievement of that studio- whether contemporary with sixteenthcentury Paris, or eighteenth-century Parma, or nineteenth-century Londonlifts us above the hurly-burly of our day.

In September 2000, Theo Rehak, proprietor of the Dale Guild Type Founder, delighted the typographic world by exhibiting at an annual fair for the makers of fine press books (Oak Knoll Books Book Fest VII) a full font recasting of the types originally cut for the 42 line Bible. I have "cut-andpasted" selections from an email message posted to Letpress: The Letterpress Discussion List—one of many on this topic, which is itself one of many topics about Gutenberg that turn up on the list.

The author of the post uses all capital letters to herald the existence of Rehak's font, and throughout his first paragraph resorts to caps for selective emphasis. ${ }^{7}$ This feat has "never been done-ever!" appears in caps, bearing the added weight of an exclamation point. This typographic redundancy provides a visual analogue to the redundancy of Rehak's font, whose uniqueness the author nonetheless insists upon, twice, as he repeats himself in the next sentence. (Note, too, the emphatic parallel doubling of "never. 
. ever." The doubling that somehow constitutes a single, original event radiates into the author's visual and syntactic representations. There is a visceral sense of something flowing from a center outward into circumambient phenomena, and of contiguous entities-e.g., representation, syntaxtranscending their contiguousness and organically becoming one.)

While the lack of commercial advantage has discouraged typefounders from attempting the feat before, Rehak's font ignores pecuniary consideration, for it possesses iconic status and will serve as "a memorial to the genius of Gutenberg." Now that matrices exist, fonts can be sold to museums, and now anyone can "attempt setting type, as it was done by the first printer and his successors." (In other words, the new Gutenberg font enables a typographic imitatio dei.)

These comparisons are not really intended to parody religion, or deconstruct typographic rapture, or imply a belittling difference from raptures induced by other, commoner, or more intimate means (by romantic love, for instance). My intention is to delineate rapture's moving parts beneath the cool integument of modern culture. To suggest how religious meanings are camouflaged within the actual bibliographic activities constellated in time as we understand it ("just one damn thing after another"), or to reveal typography as an instance of "the religious creativity of modern societies" (Reconstructing, 216; History of Religious Ideas, xvi).

The post concludes with a resounding affirmation of letterpress and an ironic, although genuine, call to arms, in quasi-apocalyptic language: "There really is life in Letterpress! But, we need to attract the attention of people out there in the 'real' world." Eliade adjudicates the question of which world is "real" (and which is real) with reference to originality or extratemporality.

The first dance, the first duel, the first fishing expedition, like the first marriage ceremony or the first ritual, became examples for humanity because they revealed a mode of existence of the divinity, of the primordial man, of the civilizing Hero. But these revelations occurred in mythical time, at the extratemporal instant of the beginning; thus ... everything in a certain sense coincided with the beginning of the world, with the cosmogony. (Myth, I05). 
In the sense that it stands at the mythical beginning of history-a time Eliade tells us is eternally present-Theo's "Gutenberg" font "really exists." Through the institutionalized authority and implementation of museum education programs, it will, as Eliade suggests (in the quotation included in my abstract), "confer a meaning upon human existence" ("Structure and Changes in the History of Religion," 366). People will know they live in a real world, a world permeated with power and no longer void of course, because the intervention of the historical moment, implicit in the breakaway scare quotes, will no longer exist.

Paradoxically, the casting of an absolutely derivative font figures as a reactualization of the absolutely original cosmogony, annulling time. The tension between earlier and later, which is insignificant except insofar as the entire scaffolding of Aristotelian time depends upon it, has been transcended.

Unlike the perfectionist, guild-sanctioned, technique-conscious bookmakers, book artists do not offer obvious examples of valorized repetition, iconic alphabets, or a clearly distinguished paradigm of archetypal power, like Gutenberg. However, book artists do model a kind of faith in the occult, in exotic mysteries, and in a recovery of lost secrets and powers. In their iconoclasm and defiance of traditional technologies, there is an Emersonian aversion to the hierarchical social structures technology engenders. American historian John Higham, noted the peculiarly technological character of bureaucracy in his 1974 presidential address before the Organization of American Historians.

Technical unity connects people by occupational functions rather than ideological faith. It rests on specialized knowledge rather than general beliefs. It has had transforming effects in virtually every sphere of life. As a method of production, technical integration materialized early in the factory system. As a structure of authority, it has taken the form of bureaucracy. As a system of values, it endorses a certain kind of interdependence, embodied in the image of the machine. Technical relations are machinelike in being impersonal, utilitarian, and functionally interlocking. Since the Civil War the growth of technical unity has been the most important single tendency in American social history; and its end is not yet in sight (Hanging Together, I5). 


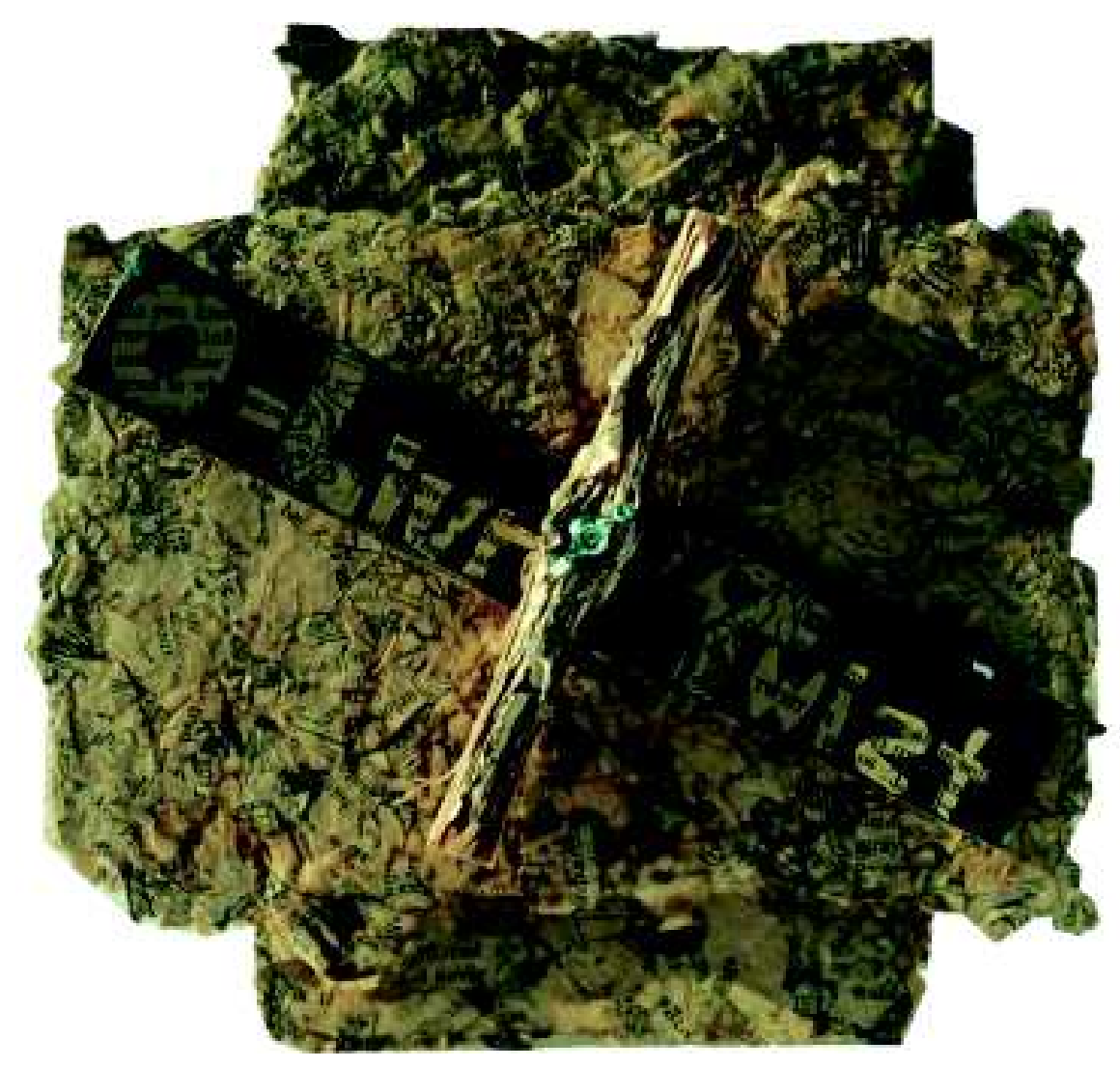

Figure 5.2 O-Livre-Twist, Maria Pisano(C) Memory Press, I994-I996. The Book Reborn. 
In part, the eclectic creativity of book artists echoes the troubled responses of nineteenth-century humanists to the social and cultural impositions of the machine (whose sine qua non is the clock, of course). The book artists' movement also coincides with a radical redefining of The Book, and with earnest, eschatological pronouncements about its death, which tellingly resonate the Death-of-God theology of Thomas Altizer. The world was very different in the 1960s and 1970s, when Altizer's radical eschatology perturbed even the popular press, and Lucy R. Lippard, Ulises Carión, Ed Ruscha, Richard Kostelanetz, and others created and theorized artists' books. Like artists of the concurrent conceptual movement, Lippard rebelled against the commodification of the art object by a capitalist society and, as she writes in "The Artist's Book Goes Public," "the elitism of the art world." Artists' books were made to be had by anyone. Her complaint against commerce and the trivialization of art is to some extent reminiscent of the fulminations of William Morris, with its implicit appeal to a marriage of aesthetic theory and militant anticapitalism. The urge to make art objects universally available, an impulse revived, with naïve exuberance, in the propagation of book art on the Internet, might be interpreted as a symbolical devalorization of labor (handicraft), and privilege (connoisseurship), two markers of the historically determined moment. Excepting The Book qua the artists' book from commercial mediation, Lippard sought to efface the horizon by which modernity "counts" events with respect to motion: time is money.

In "The Artist as Book Printer," ${ }^{10}$ Betsy Davids and Jim Petrillo describe what philosophers or historians of religion, and anthropologists would recognize as rite of self-sacrifice. ${ }^{\text {II }}$

It's the last scene of the final act and (the artist as tenor) has just stepped off the top of the citadel. On the way down he sings his concluding aria: "There are more producers of artists books than there are consumers. It's true democracy and bad business." Stage left, one can make out the shadowy figure of the Muse, who points an enigmatic finger at the words projected on the scrim over the badly painted sunrise: "The book as it will be is yet to be discovered." (I60) 
Every sacrifice "exactly reproduces the initial sacrifice revealed by a god ab origine, at the beginning of time, [and] takes place at that primordial mythical moment" (Myth, 35). Notice that the Muse materializes at the very moment of the artist's death. Notice, too, in her prophecy, that "the book ... yet to be," which exists apart, as some teleological, preconceptual form, will materialize only after "the last scene of the final act," in other words, only after the utter disappearance of historical time, which is the occasion figured by dramaturgy - the artificial time of every performance. The artist's death, since it occurs at the exact moment of the first sacrifice, in That Time (Eliade's illo tempore), allows mythic time to gush forth and revitalize The Book. The emblematic image Davids and Petrillo offer valorizes the efforts of book artists to destroy the entropic language of the historical book, or the book of history. In their creative view, the book becomes an ambiguous symbol, a coincidentia oppositorum. That is, a metaphor for history-for the hierarchical distinctions signified by the binary pairs of consumer/producer, art/ business - and, also (The Book), a metaphor for the transhistorical moment, the immutable moment outside history, the beginning. Paradoxically, at the enigmatic moment of total eclipse, Anukuklosis begins: The dying Book engenders its rebirth.

The extraordinary mutation of artists' books into materialistic commodities over the last two decades has multiplied the pressures brought against the historical book, introducing elements of ridicule, elitism, and anarchy into an increasingly fractious fray. Just as, at the end of the nineteenth century, William Morris destabilized the historical book qua text by foregrounding its objective, artifactual existence, at the end of the twentieth century book artists wildly, perhaps orgiastically, privileged the artifact over text, accelerating the destabilization begun by Morris. Their purpose not only appears to run contrary to the conventional objectives of decoration, representation, and interpretation as conceived and valued by traditional book illustrators, it is contrary. (Image \& Text, I3). Book artists have intended nothing short of the destruction of the languages perpetuated within the bibliographic culture. The exemplary pattern beheld by bookmakers in the technology and culture of the book is missing from their perceptions. It is absent from their worldview. In their view, consolidated against the bibliographic, the sole means of restoring paradise is to ensure that the encrustation of time (i.e., the historical book in all its articulated forms) be reduced to nothing. ${ }^{12}$ 
In the role of village explainer, the artist Richard Minsky has argued that the antecedents of The Book are to be found in the prehistoric marks on cave walls. ${ }^{13}$ This is not an argument as such, since inductive or deductive reasoning cannot prove or disprove it; nor can one corroborate through personal experience that the artists in Lascaux or Altimara had some comprehensible bookish idea or vision. It is therefore, not a rational discourse but an emotive appeal to our sense of wonder at the inconceivable immensity of the Paleolithic era: a rhetorical trope in the mold of Davids and Petrillo. Minsky offers his own hieratic narrative in place of their oracular muse, evokes prehistory, rather than an eschatological post-history, and employs perhaps a more sophisticated irony, but the myth shines through all the same. By referencing sacred time, each author constructs The Book as a transhistorical force that cannot be defined within a consciousness awakened only to the historical moment. For those who can accept their premises, The Book becomes what Rennie calls a "non-historical category," whose ontic waters irrigate the enterprise of book artists, the toilers in eternity, with lasting power.

Sacralizing ideal and non-historical categories we appeal to illud tempus (i.e., That Time) to justify our privileging of one [experience] over another, of the sacred over the profane, and thus we evoke mythical structures. The secular modern does this no less than the traditional religious. (Changing, xv)

The invocation of antiquity in defense of the postmodern is a striking reminder of the contradictory impulse at the heart of the artists' book movement, namely, to name things, books, that seem not to be-for example, the foundational garments of Miriam Schaer and Susannah B. Troy, the coffee bags and Mallomar wrappings of Suellen Glashausser, tangled yarn, shoes, and so forth. The point is, these whimsical assaults upon "the book beautiful" are all evacuations of the historical detritus that constitutes the authenticity of Time, of historical containment, of finality. By contesting their hegemony, book artists resist being immured or interred in the historical moment, to which Sartre fatally insisted we must pay complete attention.

This prevalent and perhaps definitive tendency of book artists suggests a symbolism that we also find in contemporary criticism. For example, in an extended riff on The Book in an essay entitled "Critical Metalanguage," 
Johanna Drucker reads reading as "Blindness and the raw face of insight staring back from the pages and into the backlit screen of the mind." She adorns the reciprocal dynamic between reader and book, which is embodied in the reversed image of the subject/object relationship, within the double helix of "blindness and insight." Drucker posits a classical allusion that besides lending the metaphor rhetorical muscle, opens strangely and selfconsciously into indeterminacy. Which classical figure are we, the notional reader, supposed to enact as we read this notional mirror book?

Are we, for example, the blind prophet Teiresias, whose name, significantly, means "he who delights in signs"? According to Callimachus, Athene blinded Teiresias by laying her hands on his eyes after he accidentally surprised her in her bath, but then "gave him inward sight by way of a compensation" (Greek Myths, 98).

Or, are we, perhaps, the prophetess of Mother Earth, the Sybil, momentarily blinded in her transports of ecstasy? Is the "screen of our mind" backlit, like that of the ponderous Sybil, by the twittering truths of demons and familiars, the infernal wisdom of the dead - and here we might remember Nabokov's definition of the library as the "citadel of illusion"? Or, does the back light originate in the celestial dazzle of a naked goddess, her "pristine" form glimpsed once in an all but forgotten past, now recollected in tranquility? (White Goddess, I05, 254). Perhaps the point that can be recovered from Drucker's insight is that insight itself - that which elicits the sacred or discloses "the qualitative dimension of human experience"-is gained by forging past the handicap of all such arbitrary distinctions, the quantifications by which we slide securely graveward.

\section{Works Cited}

Artists'Books: A Critical Anthology and Sourcebook, edited by Joan Lyons. Layton, Utah: Gibbs M. Smith, Inc., in Association with Visual Studies Workshop Press, 1985.

Bergson, Henri. Time and Free Will: An Essay on the Immediate Data of Consciousness. Trans. F.L. Pogson. London, G. Allen \& Unwin; New York: Humanities Press, 197I.

Drucker, Johanna. Figuring the Word: Essays on Books, Writing and Visual Poetics. New York: Granary Books, 1998. 
Eliade, Mircea. History of Religious Ideas. Trans. Willard R. Trask. Chicago: University of Chicago Press, c. 1978-.

The Myth of The Eternal Return. Trans. Willard R. Trask. New York: Harper, I97I.

The Sacred and the Profane. Trans. Willard. R. Trask. New York: Harper, I96I.

"Structure and Changes in the History of Religion." In City Invincible - A Symposium of Urbanisation and Cultural Development in the Ancient Near East, edited by C. Kraeling and R. Adams. Chicago: University of Chicago Press, 1960.

Franklin, Colin. The Private Presses. 2nd ed. Aldershot, Hants, England: Scolar Press; Brookfield, Vt.: Gower Pub. Co., I99I.

Graves, Robert. Collected Poems I959. London: Cassell, I959.

—_The Greek Myths. 2Vols. New York: Penguin, 1955.

The White Goddess: A Historical Grammar of Poetic Myth. Amended and enlarged ed. New York: Farrar, Strauss and Giroux, 1948.

Heidegger, Martin. Being and Time. Trans. J. Macquarrie and E. Robinson. Oxford: Basil Blackwell, I988.

Higham, John. Hanging Together: Unity and Diversity in American Culture. New Haven and London: Yale University Press, 2001.

Hodnett, Edward. Image \& Text: Studies in the Illustration of English Literature. London:Scolar Press, 1982.

Kallas, Triin. Time and Temporality in the Early Thought of Martin Heidegger. http://www.ehi.ee/ehi/oppetool/lopetajad/triink/index.html.

Changing Religious Worlds: The Meaning andEnd of MirceaEliade. Rennie, Bryan; ed. New York: State University of New York Press, 2001.

Rennie, Bryan S. Reconstructing Eliade: Making Sense of Religion. New York: State University of New York Press, 1996.

Yeats,W.B. (William Butler). The Collected Poems of W.B. Yeats. Definitive ed. with the author's final revisions. New York: Macmillan, I956. 
Notes

I Time andTemporality in the Early Thought of Martin Heidegger,http://www.ehi.ee/ ehi/oppetool/lopetajad/triink/; Being and Time, translated by J. Macquarrie and E. Robinson. Oxford: Basil Blackwell, 1988.

2 The broadest definition in Bryan S. Rennie's valuable discussion of the different histories is "history as the totality of human experiences" (Reconstructing, 90).

3 Rennie, representing Eliade's thought, describes the life-giving function of sacred history and its radical divergence from ordinary history. "It is only through 'sacred histories' that meaning can be invested in the otherwise vacuously horrible or horribly vacuous events of life itself" (Reconstructing, 99).

4 Showalter, Elaine, "A Literature of My Own: Living with Victorian Women Writers" (essay in this journal; p. 24)

5 Kerry Magruder, http://www.earthvisions.net/flatEarth/examples. htm.

6 Rennie concisely presents Eliade's notion of myth as prereflective, positive valorizations of a specific Weltanschauung (Reconstructing, 73, 244).

7 Stan Nelson, “Gutenberg's B42 is Recast," http://groups.yahoo.com/ group/letpress/message/I7097.

8 In Changing Religious Worlds, Rennie and, separately, William E. Padden suggest that different religions can be conceived of as different worlds, to which the human mind has multiple access. This idea first emerged in the work of Samuel R. Levin, who "argued that it is more coherent interpretation of the Romantic use of the metaphor [of having access to alternative worlds] that, rather than inviting an accommodation of the metaphorical expressions to a fixed world, it invites an accommodation of the world to the expression. That is to say, we can change worlds" (277).

9 Artists'Books: A Critical Anthology and Sourcebook.

I0 Ibid.

II See, for an example of anthropological insight into contemporary rites of sacrifice, Rene Girard, Violence and the Sacred(1977); The Scapegoat(I986); ISee Satan Fall Like Lightning(200I); Eric Lawrence Gans, Originary Thinking: Elements of Generative Anthropology (1993). 
I2 A Daleuzean perspective, in which the ultimate unity is difference, would make sense out of the fact that many book artists are also traditional book workers-binders, illuminators, papermakers, etc.

13 See Richard Minsky "Re: Defining a Bookm," http://palimpsest. stanford.edu/byform/mailing-lists/bookarts/I995/04/msg00026. html; Richard Minsky, “Artists' Books vs. Book Art," http:// palimpsest.stanford.edu/byform/mailing-lists/bookarts/I998/03/ msg00396.html; Richard Minsky. "Book As Art." http://palimpsest. stanford.edu/byform/mailing-lists/bookarts/2001/09/msg0004I. html. See also Peter Verhayen's concatenation of posts, "Definition of the Artist's Book; What is a Book; BSO's (Book Shaped Objects); Art vs. Craft A Discussion held on the Book_Arts-L listserv, March I998." http://www.philobiblon.com/whatisabook.htm. 